Original Research Paper

\title{
Belajar dan Bermain dengan Kreatif untuk Meningkatkan Kemampuan Membaca dan Berhitung Anak Di Dusun Berenyok Desa Mujur Kecamatan Praya Timur
}

\author{
Riani Olivia ${ }^{1}$, Miftahul Wasli ${ }^{2}$, Nirmala Sari ${ }^{3}$, Dadi Setiadi $^{4}$ \\ ${ }^{1}$ Pendidikan Matematika, Fakultas Keguruan dan Ilmu Pendidikan, Universitas Mataram, Mataram, Indonesia \\ ${ }^{2}$ Pendidikan Fisika, Fakultas Keguruan dan Ilmu Pendidikan, Universitas Mataram, Mataram, Indonesia \\ ${ }^{3}$ Pendidikan Matematika, Fakultas Keguruan dan Ilmu Pendidikan, Universitas Mataram, Mataram, Indonesia \\ ${ }^{4}$ Dosen Pendidikan Biologi, Fakultas Keguruan dan Ilmu Pendidikan, Universitas Mataram, Mataram, Indonesia
}

https://doi.org/10.29303/jpmpi.v3i2.1448

Sitasi: Olivia, R., Wasli, M., Sari, N \& Setiadi, D. (2022). Belajar dan Bermain dengan Kreatif untuk Meningkatkan Kemampuan Membaca dan Berhitung Anak Di Dusun Berenyok Desa Mujur Kecamatan Praya Timur. Jurnal Pengabdian Magister Pendidikan IPA, 5(1).

\section{Article history}

Received: 21 Januari 2022

Revised: 15 Februari 2022

Accepted: 27 Februari 2022

*Corresponding Author: Riani

Olivia, Pendidikan

Matematika, Fakultas

Keguruan dan Ilmu Pendidikan, Universitas Mataram, Mataram, Indonesia

Email:

rianiolivia186@gmail.com

\begin{abstract}
Tingkat kemampuan membaca dan berhitung pada siswa di Dusun Berenyok Desa Mujur Lombok Tengah masih terbilang rendah, hal ini dilihat dari hasil pembelajaran yang telah dilakukan selama kegiatan KKN Terpadu berlangsung. Tujuan dari pengadaan kegiatan belajar - mengajar selain membantu orang tua siswa juga untuk memotivasi para peserta didik untuk lebih giat belajar dan mengerjakan tugas-tugas dari sekolah dengan semangat. Metode yang digunakan yaitu pendampingan siswa melalui kegiatan bimbingan belajar dan bermain yang dilaksanakan di masjid yang bertempat di Dusun Berenyok Desa Mujur Kecamatan Praya Timur Kabupaten Lombok Tengah. Pelaksanaan kegiatan ini dilakukan dua kali seminggu yaitu hari Rabu dan Kamis selama tujuh minggu pada bulan November sampai bulan Januari 2021, pada pukul 16.00 WITA hingga 17.30 WITA. Teknik pengumpulan data secara tes untuk mengetahui perkembangan prestasi belajar siswa, dan secara non tes dengan wawancara untuk mengetahui motivasi belajar siswa. Hasil menunjukkan pembelajaran dengan menggunakan konsep bermain sangat efektif dalam meningkatkan kemampuan membaca anak dan dapat meningkatkan kemampuan berhitung permulaan pada anak.
\end{abstract}

Keywords: Belajar dan bermain, membaca, berhitung.

\section{Pendahuluan}

Mencerdaskan kehidupan bangsa merupakan salah satu tujuan nasional Republik Indonesia yang tercantum dalam pembukaan UUD 1945. Upaya pemerintah dalam mengembangkan kemampuan dan membentuk peradaban bangsa yang bermartabat yaitu dengan cara memenuhi pendidikan setiap warga negaranya agar tercapai tujuan nasional. Pendidikan menjadi salah satu tolak ukur dalam menentukan kualitas suatu negara. Pendidikan mempunyai peranan penting dalam menumbuhkan kecakapan generasi penerus bangsa agar mampu bersaing secara global dalam menghadapi dan memecahkan permasalahan dunia. Pendidikan yang berkualitas dan bermutu dapat melahirkan sumber daya manusia (SDM) yang unggul, baik dari aspek pengetahuan, sikap, dan keterampilan. Pendidikan juga merupakan 
serangkaian proses belajar yang harus dilalui oleh setiap orang untuk mencapai kehidupan yang lebih baik.

Belajar adalah suatu kegiatan yang dilakukan secara sadar untuk mencapai perubahan dalam diri individu. Perubahan tersebut mencakup tingkah laku, pengetahuan, dan keterampilan (Khairani, 2017). Belajar merupakan suatu proses usaha sadar yang dilakukan oleh individu untuk suatu perubahan dari tidak tahu menjadi tahu (Humanistik, 2002). Belajar tidak hanya dimulai dari sekolah, tetapi sudah dimulai sejak dini baik berawal dari lingkungan keluarga maupun masyarakat sekitar. Seperti yang tercantum dalam Undang Undang Nomor 20 Tahun 2003 dimana pembelajaran diartikan sebagai proses interaksi peserta didik, guru, dan sumber belajar pada suatu lingkungan belajar (Suri, 2020).

Pengadaan kegiatan belajar-mengajar selain membantu para orang tua siswa juga untuk memotivasi para peserta didik untuk lebih giat belajar dan mengerjakan tugas-tugas dari sekolah dengan semangat. Motivasi yang kami berikan yaitu dengan metode belajar yang menyenangkan yaitu belajar sambil bermain. Kegiatan ini sangat bermanfaat bagi para peserta didik karena dengan adanya bimbingan belajar ini memberikan motivasi belajar lebih giat serta membantu para peserta didik untuk menyelesaikan tugas-tugas dari sekolah. Selain itu membantu peserta didik untuk menghadapi ujian semester.

Rendahnya kemampuan membaca, menulis dan berhitung pada siswa di Dusun Berenyok Desa Mujur disebabkan salah satunya adalah suasana belajar yang kurang menyenangkan dan kurangnya interaksi yang aktif antara guru dan siswa. Pembelajaran membaca, menulis dan berhitung bukan lagi sebuah mata pelajaran yang seharusnya dapat membantu dalam pemecahan permasalah pada mata pelajaran lain, justru malah penghambat motivasi siswa untuk belajar. Oleh karena itu, penulis memfokuskan penelitian sebagai berikut bagaimana belajar dengan bermain dalam meningkatkan kemampuan membaca dan berhitung permulaan.

\section{Metode}

Pada kegiatan pengabdian yang dilakukan oleh mahasiswa KKN Terpadu Universitas
Mataram di Desa Mujur, pendidikan merupakan hal yang menjadi sasaran utama, yaitu bagaimana cara menumbuhkan motivasi dan minat belajar siswa melalui kegiatan belajar dan bermain. Selain itu, dalam rangka meningkatkan motivasi belajar siswa perlu melibatkan orangtua. Karena apabila orang tua acuh terhadap proses pembelajaran yang dilalui siswa maka motivasi siswa belajar akan sulit untuk muncul. Oleh karena itu, untuk mengatasi masalah tersebut maka metode yang digunakan yaitu pendampingan siswa melalui kegiatan bimbingan belajar dan bermain yang dilaksanakan di masjid yang bertempat di Dusun Berenyok Desa Mujur Kecamatan Praya Timur Kabupaten Lombok Tengah. Teknik pengumpulan data secara tes untuk mengetahui perkembangan prestasi belajar siswa, dan secara non tes dengan wawancara untuk mengetahui motivasi belajar siswa.

Kegiatan ini diikuti oleh partisipasi siswa TK, SD/MI, dan SMP di Dusun Berenyok dengan jumlah total siswa yang mengikuti kegiatan belajar dan bermain sebanyak \pm 50 siswa. Fasilitas yang digunakan untuk menunjang pelaksanaan kegiatan adalah alat tulis, papan tulis, buku pelajaran siswa, buku gambar, dan pensil warna (krayon). Pelaksanaan kegiatan ini dilakukan dua kali seminggu yaitu hari Rabu dan Kamis selama tujuh minggu pada bulan November sampai bulan Januari 2021, pada pukul 16.00 WITA hingga 17.30 WITA. Pelaksanaan kegiatan belajar dan bermain ini yaitu berupa pemberian motivasi kepada siswa dalam belajar, membantu siswa dalam membaca dan berhitung, serta pemberian reward (hadiah) berupa pujian/penghargaan secara lisan dan berupa barang.

\section{Hasil dan Pembahasan}

\section{Membaca Permulaan}

Pemilihan permainan yang sinkron dengan belajar membaca dan berhitung yang tepat akan sangat mempengaruhi keberhasilan proses pembelajaran. Pemilihan media pembelajaran dan alat permainan yang tidak tepat dapat mempengaruhi suasana hati dan kegembiraan anak, sehingga dapat mempengaruhi keceriaan anak. proses pembelajaran dengan membaca dan berhitung sambil bernyanyi dapat meningkatkan motivasi belajar anak. Bermain dengan kreatif yang digunakan telah disesuaikan dengan kemampuan anak, sehingga menciptakan suasana kegembiraan dalam proses pembelajaran. 
Dari hasil pengamatan terhadap anak-anak di Dusun Berenyok dapat disimpulkan bahwa pembelajaran dengan menggunakan konsep bermain kreatif sangat efektif dalam meningkatkan kemampuan membaca anak. Hal ini berarti bermain kreatif merupakan salah satu komponen yang harus dikembangkan oleh guru dan orang tua dalam proses belajar mengajar, karena peranannya sangat penting sebagai alat bantu untuk menciptakan proses belajar mengajar secara efektif. Dalam pembelajaran, media memiliki beberapa manfaat antara lain sebagai berikut: a) Penyampaian materi pembelajaran dapat diseragamkan; b) Proses pembelajaran menjadi lebih jelas dan menarik; c) Proses pembelajaran menjadi lebih interaktif; d) Efisiensi dalam waktu dan tenaga; e) Meningkatkan kualitas hasil belajar siswa; f) Media memungkinkan proses belajar dapat dilakukan dimana saja dan kapan saja; g) Media dapat menumbuhkan sikap positif siswa terhadap materi dan proses belajar; h) Merubah peran guru ke arah yang lebih positif dan produktif ( Karo-karo dan Rohani, 2018).

Pada saat mengajar membaca anak, perlu diciptakan suasana bermain karena anak identic dengan bermain. Dengan suasana bermain sambil belajar, pengalaman anak dalam belajar membaca akan sangat menarik. Suasana menyenangkan yang ditimbulkan pada akhirnya akan membuat anak semakin baik dalam belajar membaca.

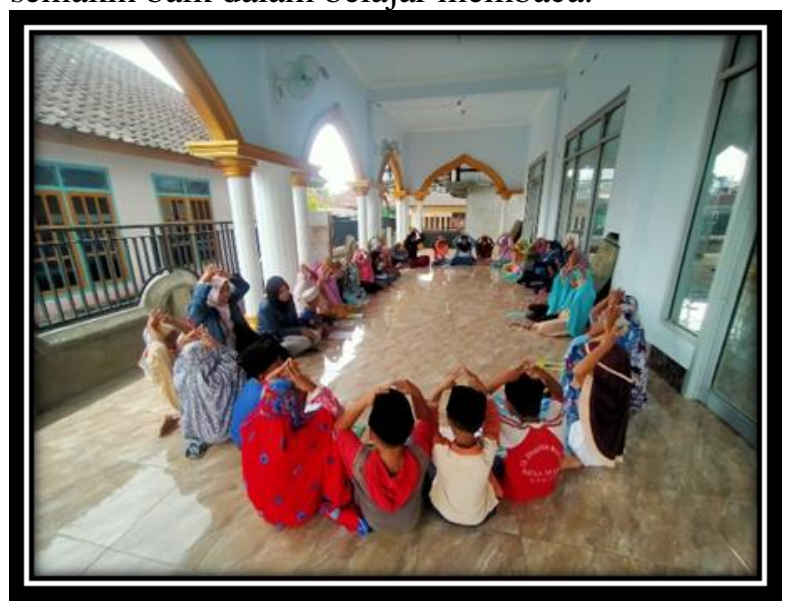

Gambar 1 Belajar dan Bermain

\section{Berhitung Permulaan}

Hasil pengamatan menunjukkan belajar dengan menggunakan konsep bermain kreatif dapat meningkatkan kemampuan berhitung permulaan pada anak. Dalam memilih permainan yang kreatif dapat memberi stimulus bagi perkembangan kemampuan berhitung permulaan pada anak. Melalui pengulangan akan membentuk kebiasaan yang merupakan hasil belajar siswa. Pembelajaran yang efektif dapat dilihat dari proses pembelajaran yang berjalan dengan menyenangkan. Sesuai pendapat Yew (dalam Halim, dkk. 2014) bahwa salah satu prinsip pembelajaran berhitung dengan cara membuat pelajaran menjadi menyenangkan. Artinya anak-anak terlibat langsung dalam pembelajaran dengan menyebutkan jumlah atau selisih yang diminta oleh guru dengan tetap memperhatikan karakteristik dan kebutuhan anak didik, selain itu melibatkan anak dalam proses permainan yang akan dibuat secara bersama-sama sehingga anak dapat membuat ide atau gagasan dari permainan tersebut, kemampuan anak dalam hal ini semakin berkembang dan baik, sehingga pembelajaran dapat tercapai.

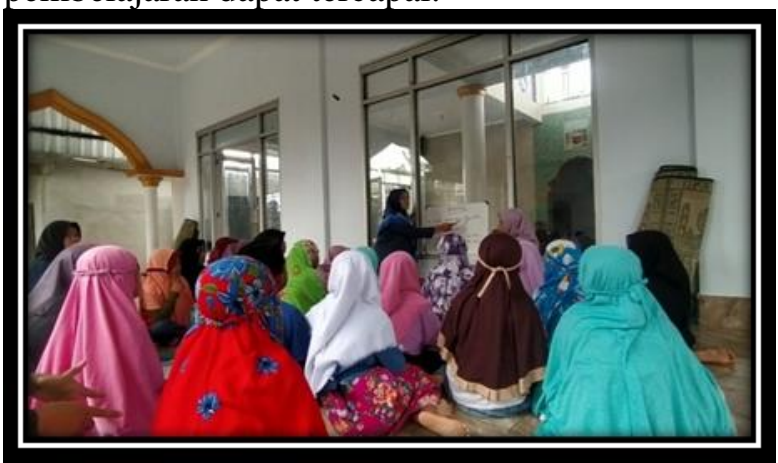

Gambar 2 Belajar Berhitung

Dalam mengembangkan kemampuan berhitung pada anak dapat dilakukan dengan berbagai cara, demikian menurut Renew (dalam Halim, dkk. 2014)) bahwa permulaan pada anak dilakukan dengan permainan-permainan yang menyenangkan suasana belajar dan mengajar yang menggembirakan dan bagaimana anak tertarik untuk belajar.

Berdasarkan pemaparan diatas maka belajar dengan bermain kreatif terlihat adanya peningkatan kemampuan berhitung permulaan anak, karena permainan dengan bermain kreatif dapat merangsang anak lebih cepat mengenal angka, membuat minat anak semakin tinggi dalam menguasai konsep berhitung permulaan mendorong kecerdasan dan ingatan anak.

Selain itu anamampu mengembangkan pengetahuannya, karena anak dapat memiliki konsep berhitung dengan baik dan anak akan mengembangkan segenap potensi yang ada pada dirinya sesuai dengan kemampuannya dan anak 
juga akan banyak belajar mengenai urutan bilangan dan pemahaman konsep angka dengan baik.

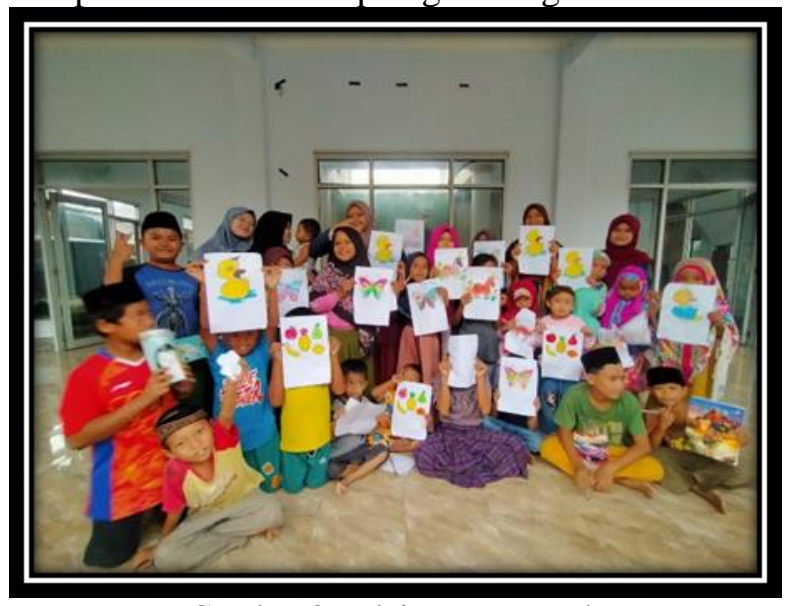

Gambar 3 Belajar Menggambar

\section{Kesimpulan}

Dari uraian diatas dapat disimpulkan bahwa pendampingan siswa dalam belajar dengan bermain kreatif dalam meningkatkan membaca dan berhitung anak yang dilaksanakan di masjid yang bertempat di Dusun Berenyok Desa Mujur Kecamatan Praya Timur. Kegiatan pembimbingan belajar ini merupakan salah satu program kerja KKN Terpadu Universitas Mataram di Desa Mujur. Tingkat kemampuan membaca dan berhitung pada Siswa di dusun berenyok masih terbilang rendah, untuk itu kami mengadakan kegiatan pendampingan melalui bimbingan belajar dengan menggunakan konsep bermain kreatif. pemberian motivasi pada siswa merupakan salah satu hal yang penting untuk meningkatkan minat belajar siswa. Dimana siswa akan merasa senang dengan pelajaran yang diberikan sehingga mudah untuk dipahami.

Dari penelitian ini diperoleh bahwa kegiatan pendampingan melalui bimbingan belajar dengan menggunakan konsep bermain kreatif sangat efektif dalam meningkatkan kemampuan membaca dan berhitung anak. Hal tersebut dapat dilihat dari hasil pengumpulan data secara tes dan non tes untuk mengetahui perkembangan membaca dan berhitung permulaan pada anak.

\section{Saran}

Diharapkan kepada peneliti selanjutnya untuk lebih memahami cara mengajar yang menarik agar siswa tidak mudah bosan saat belajar, dan juga dapat mengembangkan strategi pembelajaran yang tepat digunakan untuk siswa pada jenjang masingmasing.

\section{Ucapan Terima Kasih}

Ucapan terima kasih disampaikan kepada dosen pembimbing lapangan atas dukungannya selama pelaksanaan kegiatan KKN, bapak kepala Desa Mujur atas dukungannya selama kami menjalankan KKN dan Kepala Dusun serta masyarakat atas dukungan dan partisipasinya.

\section{Daftar Pustaka}

Khairani, M. 2017. Psikologi Belajar. Yogyakarta: Aswaja Pressindo.

Suri, N. (2020). Realisasi Musyawarah Guru Mata Pelajaran (MGMP) Dalam Menunjang Tugas Dan Fungsi Guru PAI di Dalam Pembelajaran di SMP Al-Fath Cirendeu.

Humansitik, B. (2002). A. Belajar dan Pembelajaran.

Karo-Karo, I. R., \& Rohani, R. (2018). Manfaat media dalam pembelajaran. AXIOM: Jurnal Pendidikan Dan Matematika, 7(1).

Is, M. J., Halim, F., \& Santi, Y. (2014). Konsep Belajar dengan Bermain Kreatif dalam Upaya Meningkatkan Kemampuan Membaca Dan Berhitung Permulaan Pada Anak Usia Dini (Penelitian Kuasi Eksperimen pada PAUD/TK Kecamatan Peusangan Kabupaten Bireuen). Lentera: Jurnal Ilmiah Sains dan Teknologi, 14(1), 146846. 